\title{
Contributions of Self-Regulated Learning, Disposition Mathematically and Habits of Mind Against Mathematical Problem Solving Ability Students
}

\author{
Nurul Afifah Hasibuan ${ }^{1}$, Nurjanah ${ }^{2}$ \\ \{nurulafifah2018@upi.edu ${ }^{1}$, nurjanah@upi.edu ${ }^{2}$ \}
}

\begin{abstract}
Program Studi Pendidikan Matematika, Sekolah Pasca Sarjana Universitas Pendidikan Indonesia, Jl. Dr. Setia Budhi No. 229, Bandung 40154, Indonesia ${ }^{1}$, Departemen Pendidikan Matematika, Universitas Pendidikan Indonesia, Jl. Dr. Setia Budhi No. 229, Bandung 40154, Indonesia ${ }^{2}$
\end{abstract}

\begin{abstract}
This research aims to 1) analyze the effect of self-regulated learning (KB), mathematical disposition (DP) and habit of mind (HoM) on mathematical problem-solving ability (KMP); 2) Contribution value has given by KB, DP, HoM on KMP; and 3) identify the dominant factors to affect KMP. This research was conducted of grade 8 in one of the private junior high schools in North Sumatera, the academic year of 2018/2019 with 32 participating students which were taken with cluster random sampling technique. The research instruments used in this included mathematical problem-solving ability tests and questionnaires. Data were analyzed by Multiple Linear Regression Analysis. The result of this research is 1) KB, DP, and HoM give a positive and significant effect on KMP; 2) Contribution value has given by KB, DP, HoM respectively are $24.26 \%, 5.8 \%$ and $13.32 \%$; and 3) Factor which dominant to affect the mathematical problem-solving ability is selfregulated Learning.
\end{abstract}

Keywords: Habits of Mind, Disposition Mathematically, Habits of Mind, Mathematical Problem Solving Ability Students

\section{Introduction}

Mathematics is a subject that needs to be given to all students ranging from elementary schools to provide students with the ability to think logically, analytically, critically, creatively as well as the ability to work, in order to have the ability to acquire, manage, and use information in order to survive in a state that is always changing and uncertain and competitive [1].

The purpose of learning mathematics contained in Permendiknas no. 22 of 2006, namely that the students have the ability to: 1) understand math concepts, explain the interrelationships between concepts and apply concepts or algorithms, flexibly, accurately, efficiently, and precisely in problem-solving; 2) using reasoning on patterns and traits, doing mathematical manipulation in making generalizations, compiling evidence, or explaining mathematical ideas and statements; 3) solving problems that include problem-solving ability, designing a mathematical models, solving models and interpreting the solutions obtained;4) communicating ideas with symbols, tables, diagrams, or other media to clarify the situation or problem [2]. From the stated objectives of mathematics learning, it is clearly written that solving mathematical problems is important for every student. [3]. Mathematical problem solving is as an approach to learning describing learning that begins with the presentation of contextual problems which 
then through inductive reasoning students rediscover the concepts learned and other mathematical abilities [4].

Results and evaluation of PISA 2015 showed that the ability of students in Indonesia was still low, one for mathematics ranked 69 with an average of mathematical ability is 386 from 76 countries evaluated [5]. This shows that the mathematical problem-solving ability of students in Indonesia is still very low, so that from it is so necessary the identification of factors that influence the math problem-solving ability of students in the school. With hope when factors have been identified, it can help teachers develop lesson plans and strategies that support them.

According to Charles and Laster, there are three factors that affect the ability of a person's problem solving is 1) Factor experience, both environmental and personal such as age, content knowledge (science), knowledge of the completion strategy, knowledge of the context and content of the problem issues; 2) effective factors, such as interest, motivation, stress anxiety, tolerance ambiguities, endurance, and patience, etc; 3 ) cognitive factors, such as the ability to read, insightful (spatial ability), the ability to analyze, calculate skills and so on [6].

But in this study will have one of three factors that affect students' problem-solving abilities that affective factors, such as 1) Self-regulated of learning is defined as learning that occurs due to the influence of thoughts, feelings, and behavior of its own strategy oriented to the achievement of objectives; 2) Disposition of mathematics is the desire, consciousness, tendencies and a strong dedication to the self-learners to think and act in a positive way; and 3) Habits of Mind (the habit of thinking) is a habit - the habit of thinking mathematically on an ongoing basis through discussion activity to explore the issue of contextual support the achievement of students' mathematical thinking skills [7].

The exposure of the issue is whether these three factors effective influence on math problem-solving skills, and affective factors which are the most dominant, contributing to problem-solving ability.

\section{Research Methods}

\subsection{Research methods}

The method used in this research is quantitative research with multiple linear regression analysis for calculating the contribution value has given by $\mathrm{KB}, \mathrm{DP}$, and HoM to Mathematical Problem Solving Ability. The population is 32 in eighth-grade students at one private junior high school in the city of Medan by sampling using purposive random sampling techniques as needed in this study.

\subsection{Instrument Data}

The data used in this study are primary data is data obtained from the object studied directly. Instrument data in this study were 1) the test problem-solving ability in the form of word problems related to materials geometrical and 2) questionnaire consisting of 34 statements related 8 statements contained self-regulated learning; 10 statements related to the disposition of mathematical; and 16 statements related to Habits of Mind that affect students' mathematical problem-solving ability. 


\section{Results And Discussion}

\subsection{Result}

In identifying the contribution of self-regulated learning attitude scale, mathematical dispositions and habits of mind to the mathematical problem-solving ability of students to use SPSS software version 23. Since the data were normally distributed and linear then the next thing to do is to perform correlation to see affect self-regulated learning, disposition mathematically and habit of minds against mathematical problem-solving ability students'.

The following correlation analysis to look at the relationship between variables using the Pearson correlation test. The test results are described in Table 1.

Table 1. Correlations.

\begin{tabular}{llrrrr}
\hline & & KB & DP & HoM & KMP \\
\hline KB & Pearson Correlation & 1 & $.473^{* *}$ & $.521^{* *}$ & $.796^{* *}$ \\
& Sig. (2-tailed) & & .006 & .002 & .000 \\
& $\mathrm{~N}$ & 32 & 32 & 32 & 32 \\
DP & Pearson Correlation & $.473^{* *}$ & 1 & $.534^{* *}$ & $.668^{* *}$ \\
& Sig. (2-tailed) & .006 & & .002 & .000 \\
& $\mathrm{~N}$ & 32 & 32 & 32 & 32 \\
HoM & Pearson Correlation & $.521^{* *}$ & $.534^{* *}$ & 1 & $.750^{* *}$ \\
\cline { 2 - 6 } & Sig. (2-tailed) & .002 & .002 & & .000 \\
& $\mathrm{~N}$ & 32 & 32 & 32 & 32 \\
KMP & Pearson Correlation & $.796^{* *}$ & $.668^{* *}$ & $.750 * *$ & 1 \\
& Sig. (2-tailed) & .000 & .000 & .000 & \\
& $\mathrm{~N}$ & 32 & 32 & 32 & 32 \\
\hline
\end{tabular}

**. Correlation is significant at the 0:01 level (2-tailed).

Based on the output table above, seen from the significant value sig. (2-tailed) KB to KMP, DP to KMP as well as the HoM to KMP $0.000<0.05$ and $r$ count (Pearson correlations) KB to KMP, DP to KMP as well as the HoM to KMP each $0.796>0.349$ ( $\mathrm{r}$ table), $0.668>0.349$ and $0.750>0.349$, it can be concluded that there are a relationship/correlation significant and positive values among self-regulated learning with problem-solving ability, disposition mathematical problem-solving skills and habits of mind to the problem-solving ability.

Followed by regression analysis to see whether there is a causal relationship between variables. The test results are described in Table 2.

The equation of regression in the analysis or the study are as in Equation 1.

$$
\widehat{Y}=3.172 X_{1}+1.096 X_{2}+1.569 X_{3}-152.285
$$

This means that every any increase students 'mathematical problem-solving ability so selfregulated learning students', the disposition mathematically students' and habits of mind students also increased amounting to $3.172,1.096$, and 1.569 [8]. 
Table 2. Regression.

\begin{tabular}{rrrr}
\hline Variables & Regression Coefficients & \multicolumn{1}{l}{ tcalculated } & Sig. \\
\hline Constants & -152285 & & \\
KB & 3.172 & 5145 & 0000 \\
DP & 1.096 & 2.494 & 0019 \\
HoM & 1.569 & 3.664 & 0001 \\
F count & 44479 & & 0 \\
R square & 0827 & & \\
\hline
\end{tabular}

Furthermore, and as a final test which calculates and analyzes a table of coefficients from the regression output to see the contribution value of self-regulated learning, mathematical dispositions and habits of mind against students' mathematical problem-solving ability. The test results are described in Table 3.

Table 3. Coefficients.

\begin{tabular}{|c|c|c|c|c|c|c|}
\hline & \multirow[t]{2}{*}{ Model } & \multicolumn{2}{|c|}{ Coefficients unstandardized } & \multirow{2}{*}{$\begin{array}{c}\begin{array}{c}\text { standardized } \\
\text { Coefficients }\end{array} \\
\text { Beta }\end{array}$} & \multirow[t]{2}{*}{$\overline{\mathrm{T}}$} & \multirow[t]{2}{*}{ Sig. } \\
\hline & & $\mathrm{B}$ & Std. Error & & & \\
\hline \multirow[t]{4}{*}{1} & (Constant) & -152285 & 18419 & & -8268 & .000 \\
\hline & $\mathrm{KB}$ & 3.172 & .617 & .492 & 5145 & .000 \\
\hline & DP & 1.096 & .440 & .241 & 2,494 & .019 \\
\hline & HoM & 1.569 & .428 & .365 & 3,664 & .001 \\
\hline
\end{tabular}

a. Dependent Variable: KMP

Referring to the output coefficients regression on the Table 3, look at the column Sig. obtained the Sig. of KB namely $0.000<0.05$ (probability value) means self-regulated learning contributes significantly (directly) in influencing the mathematical problem-solving ability. The amount of direct contribution given that as many as $0.4922^{2}=0.2426 \times 100 \%=24.26 \%$.

Value Sig. DP namely $0.019<0.05$ (probability value) means a mathematical disposition, contributing significantly (directly)) in influencing the mathematical problem solving ability. The amount of direct contribution given that as many as $0.2412^{2}=0.058 \times 100 \%=5.8 \%$.

Furthermore, the Sig. of HoM namely $0.001<0.05$ (probability value) means the habits of mind, contributing significantly (directly) in influencing the mathematical problem-solving ability. The amount of direct contribution given that $0.3652^{2}=0.1332 . \times 100 \%=13.32 \%$

While the magnitude of the direct contribution given birth, DP, and HoM together to affect the ability of problem-solving as many as $0827=82.7 \%$. While the rest influenced factors/variables which can not be explained in the study [9], [10].

The following diagram path analysis KB relationship, DP and HoM on the mathematical problem-solving ability of students:

\subsection{Discussion}

The study produced several related findings, contributing self-regulated learning, mathematical dispositions and habits of minds with mathematical problem-solving ability junior 
high school students. Based on the calculation results of correlation test was obtained that there is a significant relationship and positive value between of self-regulated learning, mathematical dispositions and habits of minds with students' mathematical problem-solving ability, it means that the higher the level of self-regulated learning, disposition mathematically and habit of minds someone, the better the problem-solving ability they have.

This is reinforced NCTM statement stating that any solution to encourage students to learn math, so it can be said that learning problem solving is one way to encourage self-regulated student learning [11]. And this can be seen from the results in Table regression coefficients output has accounted for $24.26 \%$. Which means learning self-regulated formative influences in this study.

As for the disposition of mathematical Kilpatrick et al stated that the disposition should be Increased Mathematical Because it is the most important factor in determining the success of students. It can be concluded that the mathematical disposition can improve students' mathematical problem-solving ability [12]. Contribution in the amount of 5.8\%, which means mathematically positioned played a role in improving students' mathematical problem-solving abilities even if only slightly. Because according to Carr disposition and ability are two different things. Students are likely to show high disposition but do not have enough knowledge or ability-related [13]. This opinion supports and explains why the highly respected contribution provided between the disposition of mathematical and problem-solving skills of little value.

Likewise with the Habits of Mind by Gordon capable of supporting students to be thinking, reflective, and creative in problem-solving [14]. Habits of thinking mathematically conducted on an ongoing basis through discussion activity to explore the contextual issues support the achievement of the ability to think mathematically. Thus, in this study, the results obtained HoM contribution in influencing students' mathematical problem-solving ability by $13: 32 \%$. Which means HoM considerable influence.

But overall testing time troubleshooting capabilities associated with self-regulated learning, mathematical dispositions and habits of mind Together, they contributed as much as $82.7 \%$ with strong category. In line with these results as well, it can be considered for teachers that focus on the improvement of the mathematical problem-solving ability of students to pay attention to the relevant aspects and strongly support an effort to improve students' mathematical problemsolving ability.

\section{Conclusion}

Based on the results of the calculation of correlation, regression, and analysis of track structure, then gave the information objectively, as follows:

1. Learning self-reliance, Disposition Mathematically and Habit of Mind affect Mathematical Problem Solving Ability Students are significantly and positively.

2. The contribution of Self-regulated Learning, Disposition Mathematically and Habit of Mind directly influencing Mathematical Problem Solving Ability respectively by $24.26 \%, 5.8 \%, 13: 32 \%$.

3. While the magnitude of the direct contribution given birth, DP, and HoM together to affect the ability of problem-solving as many as $0827=82.7 \%$

4. Factors Self-regulated learning to be a dominant factor and superior in Mathematical Problem Solving Ability affect students. 


\section{Reference}

[1] Depdiknas.: Permendiknas RI No.22 tahun 2006 tentang standar isi untuk satuan Pendidikan dasar dan menengah. Jakarta: Depdiknas. 2006

[2] Depdiknas.: Kurikulum 2006 standard kompetensi mata pelajaran matematika SMP dan MTs. Jakarta: Depdiknas. 2006

[3] National Council of Teacher of Mathematics (NCTM). p. 29. 2000

[4] Hendriana, H \& Sumarmo, U: Penilaian Pembelajaran Matematika, Bandung: PT. Refika Aditama, p.2014

[5] OECD.: PISA 2015 result (volume 1): excellenge and equity in education. Paris: OECD Publishing. 2016

[6] Kaur, B.: Problem solving in the mathematics classroom (secondary). Singapura: National Institude of education. 2008

[7] Hendriyana, H. Rohaeti, E. \& Sumarmo, U.: Hard Skill dan Soft Skills Matematik Siswa. Bandung: PT. Refika Aditama. p. 228. 2017.

[8] William, M.: A Second Course in Statistics: Regression Analysis $\left\{7^{\text {th }}\right.$ (seventh) Edition]. Prentice Hall. p.99. 2011

[9] Riduwan \& Sunarto.: Pengantar Statistika untuk penelitian: Pendidikan, Sosial, Komunikasi, Ekonomi, dan Bisnis. Bandung: Alfabeta. p.139-168. 2012

[10] Abuxar A, et.al.: Analisis Multivariabel Suatu Pengantar. Bogo: In Media. p. 92-107. 2017

[11] Darma, Y. Firdaus, M. \& Haryadi, R.: Hubungan Kemandirian Belajar Terhadap Kemampuan Pemecahan Masalah Matematis Mahasiswa Calon Guru Matematika. Jurnal edukasi, Vol.14, No.1. pp. 177

[12] Puspitasari, E.: Pengaruh Disposisi Matematis dan Berpikir Kritis Terhadap Kemampuan Pemecahan Masalah Matematika. Jurnal Pendidikan Dasar,Vol.8. pp. 154. 2017

[13] Mahmudi, A.: Tinjauan Asosiasi antara Kemampuan Pemecahan Masalah Matematis dan Disposisi Matematis. 2010

[14] Dzulfikar, a.: Habits of Mind Calon Guru Matematika dalam Pemecahan Masalah Matematis. Suska Journal of Mathematics Education, Vol.4. pp.1-8. 2018 